\title{
ENERGY PREDICTION BASED ON MODELLING AND SIMULATION ANALYSIS OF AN ACTUAL GRID-CONNECTED PHOTOVOLTAIC POWER PLANT IN TURKEY
}

\author{
Osman CICEK ${ }^{1 *}$, Mohamed Alageli M. MILLAD ${ }^{2}$, Faruk ERKEN ${ }^{3}$
}

Turkey has invested in generating solar power industry to meet the energy demand as well as saving the national energy resources. The government has also substituted some of the energy consumption with clean energy sources, especially on-grid PV power plants. In recent years, a number of incentives are provided to persuade investors to invest in solar energy sector in Turkey. In this context, KRMN-SNAPS 1.6 MW PV power plant is installed in Konya Province in the Central Anatolia region of Turkey. The most important information that have to be known in advance are the cost and duration of the investment. Therefore, pre-investment production analysis of the PV power plant is very essential. The performance of the power plant depends on some parameters for instance temperature, irradiance and sunshine duration. In this study, solar PV arrays are modelled by using MATLAB/Simulink and the power plant is simulated based on the above mentioned meteorological parameters. The simulation results of the $P V$ power plant were compared with the actual production data. In the simulation, long-term average data on production of the location were used and it is observed that the simulation results and the one year's actual production data are compatible with each other.

Key words: Renewable energy, PV systems, on-grid PV power plants, energy prediction, energy policy.

\section{Introduction}

In the last few decades, Turkey is one of the greatest growing economical countries in the world for the most industrial fields [1]. This development has increased not only the consumption of the resources of both local and imported energy (oil, natural gas and coal) to supply all the operating needs, but also has risen the anxiety of energy resources shortage in the country [2]. Furthermore, in the developing countries, the rapid growth in population and industrialization have led to increasing the energy demands with an increase in power consumption.

Energy, as a civilization factor, is considered as one of the main indicators that can be used to recognize the economic and social development strength level of any country. This has brought out the

\footnotetext{
${ }^{1}$ Department of Electrical and Electronic Engineering, Faculty of Engineering and Architecture, Kastamonu University, Kastamonu, Turkey, (ocicek@kastamonu.edu.tr) Dhttps://orcid.org/0000-0002-2765-4165

${ }^{2}$ Kastamonu University, Faculty of Engineering and Architecture, Department of Materials Science and Nanotechnology Engineering, 37000 KASTAMONU, TURKEY, (mohamedmillad@yahoo.com)

${ }^{3}$ Department of Electrical and Electronic Engineering, Faculty of Engineering and Architecture, Kastamonu University, Kastamonu, Turkey, (ferken@kastamonu.edu.tr) 1 https://orcid.org/0000-0003-2048-1203
} 
existence of a direct proportional relationship between energy consumption and social development. Therefore, energy consumption increases with economic development and welfare [3,4].

There is no doubt that the increased demand of energy in all over the world has raised the level of $\mathrm{CO}_{2}$ emissions into the ozone layer as a result of burning petroleum products which pollute the atmosphere and cause global warming [5, 6]. Therefore, a major benefit of using Renewable Energy Sources (RESs) for instance hydroelectric, geothermal, wind, biomass, solar energy etc., is the reduction of pollutant emission in the air [7]. In addition to the benefits of RESs, the energy safety concerns have increased the importance of RESs all around the world [8-12].

RESs are also called alternative energy [13]. One of the most important alternative energy sources is solar energy, because of its ubiquity, abundance, and sustainability. [14-16]. In addition, the demands for solar applications have enhanced by $20 \%$ to $25 \%$ over the last two decades and this market is growing worldwide [17]. Turkey has approximately imported $60 \%$ of its energy sources. Turkey has an appropriate geographical location to take advantage of using sun light as a source of energy in order to meet some of the electrical demand, providing better ecological life and reducing the power cost. [18].

A number of incentives has been implemented to enhance the ratio of RESs in power generation in Turkey. As a result of these charming regulations, many solar power plant has been installed in Turkey. One of these plants is KRMN-SNAPS 1.6 MW PV power plant installed in Konya Province in the Central Anatolia region of Turkey. The efficiency and profitability of these power plants are important for investors. The energy produced from the power plant depends on many production factors for instance temperature, humidity, wind, irradiance and sunshine duration. It is important to predict the power values of the power plant based on these factors.

PV systems are used to generate electricity from solar energy, and they are classified into three main types such as on-grid connected, off-grid connected and hybrid PV system. On-grid solar systems are by far the most common and widely used in houses and power generating stations. These systems are connected to the public electricity grid and do not require a battery storage system. Grid system consists of solar panels, inverters, a power conditioning unit and grid connection equipment [19].

The most basic component of a PV system is the PV module. It is made up of several photovoltaic solar cells, which generate different amounts of direct current depending on the manufacturing substance such as mono crystalline, poly-crystalline and thin film technologies [20]. PV module is rated on the bases of the power delivered under Standard Testing Conditions (STC) i.e. a cell temperature of 25 degrees Celsius $\left({ }^{\circ} \mathrm{C}\right)$ and an irradiance of $1 \mathrm{~kW} / \mathrm{m}^{2}$ with an air mass 1.5 (AM1.5).

In this study, all the components of the power plant are simulated in MATLAB/Simulink using the actual parameters. Due to the long-term data, the power and the energy values of the power plant were estimated and compared with the actual values of 2018.

\section{Electrical Characteristics of Solar Cell}

The operating principle of PV cells is that the electron-hole pairs, which absorbs photons having energy exceeding the band-gaps of the material and so generates current when sun light sheds on PV cells depending on the irradiance [21]. Fig. 1 indicates the simplified electrical equivalent circuit of PV cell and explains its principle of operating under the illumination. 

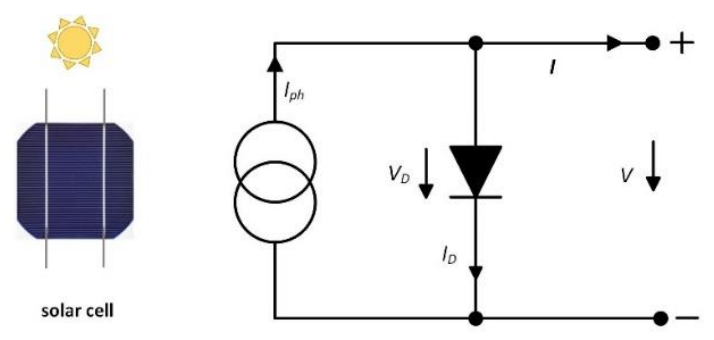

(a)

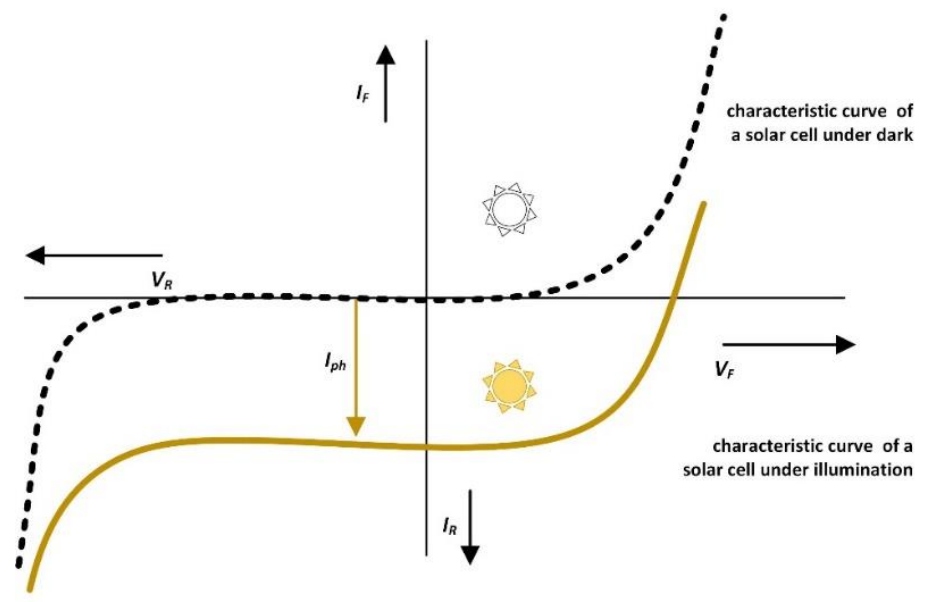

(b)

Figure 1. The ideal electrical circuit (a) and characteristic curve (b) of PV cell under the illumination [22].

The current expressions can be written according to the electrical circuit in Fig. 1 as following:

$$
\begin{aligned}
& I_{p v}=I_{p h}-I_{D} \\
& \quad I_{p v}=I_{p h}-I_{o}\left[e^{\frac{q V}{n k T}}-1\right]
\end{aligned}
$$

According to the numbers of diodes, there are two types of a solar cell equivalent circuit, the single-diode and two-diode model as shown in Fig. 2. A few milliohms of series resistance $R_{s}$ is occurred owing to the movement of current through the $p$ - $n$ junctions and the contact resistance between the metal contact and the silicon in the PV cell. Moreover, the power losses and leakage currents occur as a parallel resistance $R_{p}$ in the equivalent circuit [22].

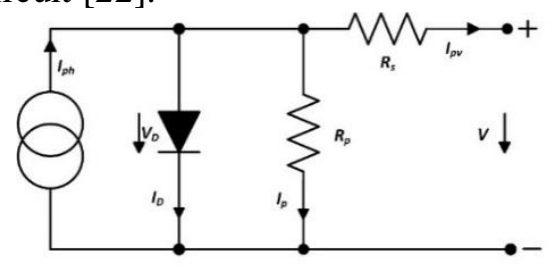

(a)

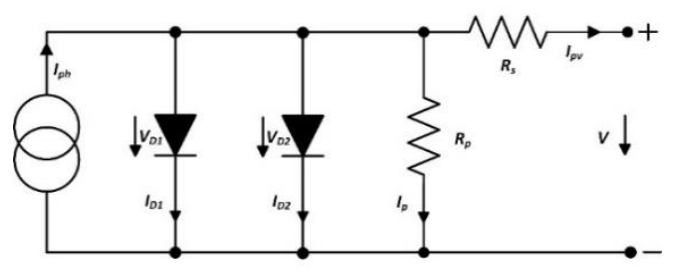

(b)

Figure 2. The single diode (a) and the two diodes (b) electrical equivalent circuit of PV cell. 
The single-diode equivalent circuit of PV cell is shown in Fig 2a. [23].Here, $I_{p h}$ and $I_{d}$ are photocurrent generated by solar radiation and the current of diode, respectively. $R_{p}$ is the parallel resistance, $I_{p}$ is the current of parallel resistance, $R_{s}$ is the series resistance, $I_{p v}$ is the current of PV module and $\mathrm{V}$ is the PV module voltage.

The basic equations of PV cell can be derived from semiconductor theory and electrical circuits analysis methods as it given below [24]:

$$
I_{p v}=I_{p h}-I_{D}-I_{p}
$$

The diode current can be written using shockley diode equation:

$$
I_{D}=I_{o}\left[e^{\frac{q\left(V+I_{p v} R_{S}\right)}{n k T}}-1\right]
$$

Here; $q$ is the electron charge $\left(1.602 \times 10^{-19} \mathrm{C}\right), n$ is the ideality factor $(1.6), I_{o}$ is the reverse saturation current of the diode, $K$ is Boltzmann constant $\left(1.38 \times 10^{-23} \mathrm{~J} / \mathrm{K}\right)$ and $T$ is the temperature in Kelvin. If the values of $I_{p}$ and $I_{D}$ are written into Eq.1:

$$
I_{p v}=I_{p h}-I_{o}\left[e^{\frac{q\left(V+I_{p v} R_{S}\right)}{n k T}}-1\right]-\frac{\left(V+I_{p v} R_{S}\right)}{R_{p}}
$$

The two diode equivalent circuit is consisted of a current source, two diodes are connected in parallel, the $R_{s}$ and the $R_{p}$ (Fig 2b). According to Kirchhoff's Law:

$$
\mathrm{I}_{\mathrm{pv}}=\mathrm{I}_{\mathrm{ph}}-\mathrm{I}_{\mathrm{D} 1}-\mathrm{I}_{\mathrm{D} 2}-\mathrm{I}_{\mathrm{p}}
$$

The currents of the two diodes can be derived from Eq.4 as:

$$
\begin{aligned}
& I_{D 1}=I_{01}\left[e^{\frac{q\left(V+I_{s} R_{s}\right)}{n k T}}-1\right] \\
& I_{D 2}=I_{02}\left[e^{\frac{q\left(V+I_{s} R_{s}\right)}{n k T}}-1\right]
\end{aligned}
$$

The equation of PV current is obtained by substituting Eq.7 and Eq.8 into Eq.6:

$$
I_{p v}=I_{p h}-I_{01}\left[e^{\frac{q\left(V+I_{p v} R_{s}\right)}{n k T}}-1\right]-I_{02}\left[e^{\frac{q\left(V+I_{p v} R_{s}\right)}{n k T}}-1\right]-\frac{\left(V+I_{p v} R_{s}\right)}{R_{p}}
$$

The $I_{P V}$ can be calculated from the above equation.

\section{Electrical Characteristics of PV Module}

PV module is constructed by connecting PV cells in series to obtain an adequate output voltage. While PV systems are commonly operated as multiples of 12 volts, PV module is typically designed for optimal operation conditions in these systems. The main target of this design is connecting of appropriate number of PV cells in series to sustain the voltage of the module $\left(V_{m}\right)$ within a comfortable range of the battery system voltage under conditions of average irradiance. Consequently, the output power of the module can be maintained close to the maximum. $V_{m}$ is normally about $80 \%$ of the open circuit voltage of the module $V_{o c}$. Silicon single cell open-circuit voltages is typically in the range of $0.5-0.6$ volts, with a generating capacity of 2 3 watts per individual cell. PV module is made up of a parallel-series configuration of PV cells as it is shown in Fig. 3. Here, Fig. 3a and b illustrate the symbol and the equivalent circuit of PV module, respectively. 


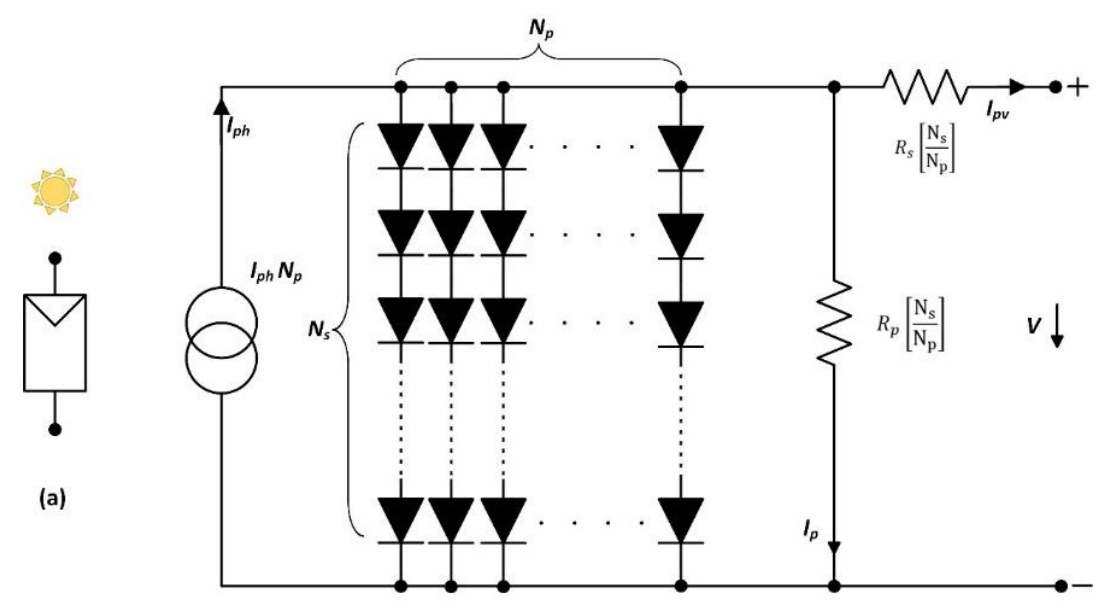

(b)

Figure 3. Symbol (a) and the equivalent electrical circuit (b) of PV module.

The PV module can be modelled mathematically as given in the next equations. PV module photocurrent is [25]:

$$
I_{p h}=\left[I_{s c}+K_{i}(T-298)\right] \frac{\mathrm{G}}{1000}
$$

PV module reverse saturation current, $I_{r s}$ and saturation current, $I_{o}$ are given as:

$$
\begin{aligned}
\mathrm{I}_{\mathrm{rs}} & =\mathrm{I}_{\mathrm{sc}} /\left[\mathrm{e}^{\left(\frac{\mathrm{qV}_{o c}}{N_{S} \mathrm{nkT}}\right)}-1\right] \\
\mathrm{I}_{\mathrm{o}} & =\mathrm{I}_{\mathrm{rs}}\left[\frac{T}{T_{r}}\right]^{3} \mathrm{e}^{\left(\frac{\mathrm{qE}_{g 0}}{\mathrm{nk}}\left(\frac{1}{T}-\frac{1}{T_{r}}\right)\right)}
\end{aligned}
$$

The output current of PV module is:

$$
\mathrm{I}_{\mathrm{pv}}=N_{p} \mathrm{I}_{\mathrm{ph}}-\mathrm{N}_{p} \mathrm{I}_{\mathrm{o}}\left[\mathrm{e}^{\left(\frac{\mathrm{q}\left(\mathrm{V}+\mathrm{I}_{\mathrm{pv}} \mathrm{R}_{\mathrm{s}}\right)}{N_{s} \mathrm{nkT}}\right)}-1\right]-\frac{\left(\mathrm{V}+\mathrm{I}_{\mathrm{pv}} \mathrm{R}_{\mathrm{s}}\right)}{\mathrm{R}_{\mathrm{p}}}
$$

Here, $N_{s}$ is the number of PV cells connected in series; $N_{p}$ is the number of the parallel connections of cells; $I_{p h} N_{p}$ is the summation of the $I_{p h}$ produced in each PV cell. $R_{s}$ and $R_{p}$ are the equivalent series and parallel resistances of the array, respectively. $I_{s c}$ is short circuit current supplied by PV module under short-circuits condition. $K_{i}$ is the short-circuit current coefficient of cell which equals to $0.0017 \mathrm{~A}$ at STC. $T$ is the operating temperature $(\mathrm{K})$ for PV module. $G$ is the solar radiation $\left(\mathrm{W} / \mathrm{m}^{2}\right) . V_{o c}$ is open circuit voltage $(\mathrm{V})$ which means lack of current; $n$ is the ideality factor of the diode which equals to 1.6. $T_{r}$ is the nominal temperature $(298.15 \mathrm{~K}) . E_{g 0}$ is the band gap energy of the semiconductor $(1.12 \mathrm{eV})$.

\section{Grid-Connected PV System Sizing}

According to the amount of energy to be produced or needed; on-line PV systems are based on the principle of consuming or transferring the generated energy to the network rather than storage in the batteries. The location selection criteria of the solar power plants directly affects the processes from the installation stage to the operation phase and the electricity production costs. Site selection is determined according to efficiency, legal regulations and environmental impact assessment criteria. 


\subsection{Geographical coordinates}

Project's name is KRMN-SNAPS 1.6 MW PV power plant is investigated. It is located within the boundaries of Çumra, which is a town and district of Konya Province in the Central Anatolia region of Turkey, at a longitude of $32.83^{\circ} \mathrm{E}$, latitude of $37.55^{\circ} \mathrm{N}$ and at an altitude of $1012 \mathrm{~m}$. The project site is approximately $1.8 \mathrm{~km}$ from Okçu neighbourhood and $5.5 \mathrm{~km}$ from Çumra center.

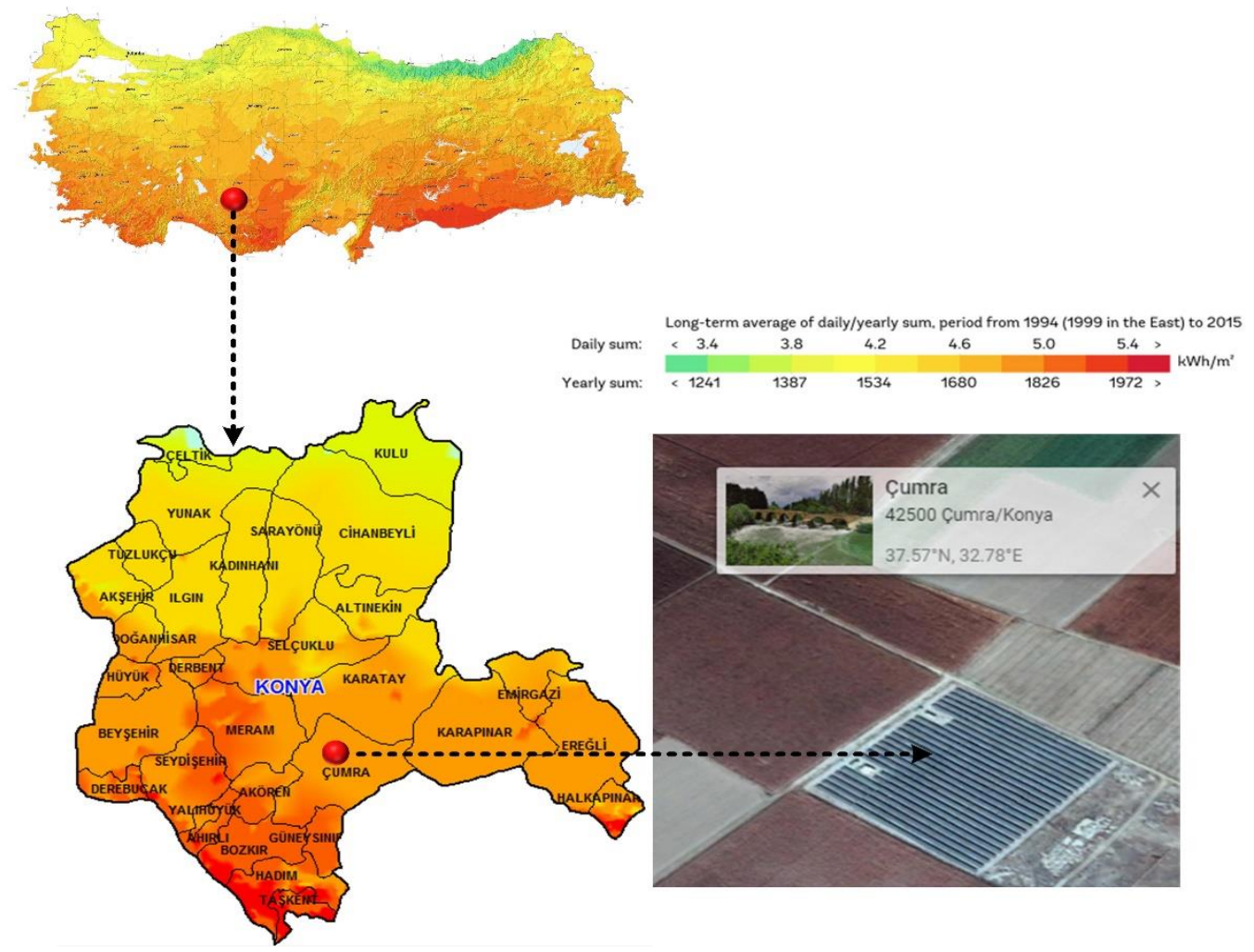

Figure 4. Long-term average of daily/yearly sum. period from 1994 to 2015 of Geographical map at a longitude $32.83^{\circ} \mathrm{E}$ of, latitude $37.55^{\circ} \mathrm{N}$ and at an altitude of $1012 \mathrm{~m}$.

\subsection{Solar radiation in the project site}

The annual average of sunshine duration in Turkey is 2640 hours. In this case, the daily average of sunshine hours is $7.2 \mathrm{~h}$. Furthermore, the country has an annual average of radiation intensity of 1311 $\mathrm{kWh} / \mathrm{m}^{2}$, which equals $3.6 \mathrm{kWh} / \mathrm{m}^{2}$ per day.

The total annual sunshine duration of KRMN-SNAPS 1.6MW in Çumra is 2985.64 hours. At the same time, the daily average of sunshine hours is $8.18 \mathrm{~h}$. Moreover, the project site has an annual average radiation intensity of $1646.55 \mathrm{kWh} / \mathrm{m}^{2}$, which equals $4.51 \mathrm{kWh} / \mathrm{m}^{2}$ per day. The total sunshine-hours and the total radiation intensity are $13.5 \%$ and $25.5 \%$ of Turkey, respectively. Global solar irradiation per $\mathrm{m}^{2}$-day and average sunshine-hours of project location during the year are shown in Fig. 5. 


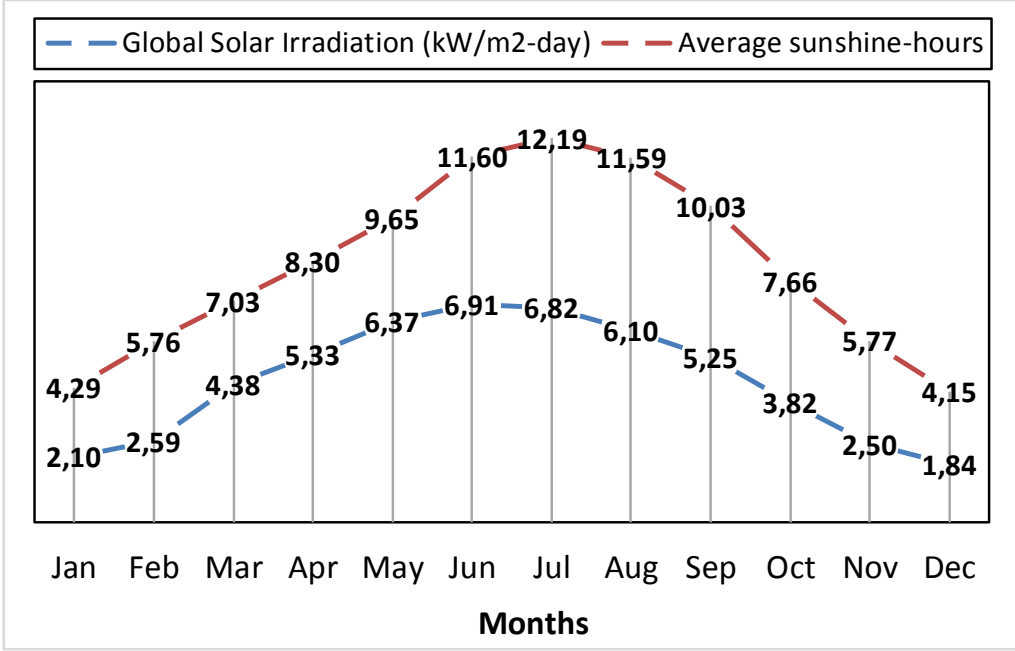

Figure 5. Global solar irradiation per $\mathbf{m}^{2}$-day and average sunshine-hours during the year in Çumra/Turkey.

Photovoltaic Geographical Information System (PVGIS) is an online free solar radiation database of the selected location in Europe, Africa, America and Asia for stand-alone or grid-connected systems or plants. Furthermore, the solar radiations data as MONTHLY, DAILY and HOURLY DATA can be supplied. Therefore, for this location, PVGIS Estimates of long-term monthly averages irradiation are given in Table 1.

Table 1. Monthly Solar Irradiation: PVGIS Estimates of long-term monthly averages for KRMN-SNAPS 1.6MW at a longitude $32.83^{\circ} \mathrm{E}$ of, latitude $37.55^{\circ} \mathrm{N}$ and at an altitude of $1012 \mathrm{~m}$ [29].

\begin{tabular}{|c|c|c|c|c|c|c|}
\hline Month & $\boldsymbol{H}_{h}$ & $\boldsymbol{H}_{\text {opt }}$ & $H(90)$ & $\boldsymbol{I}_{\text {opt }}$ & $\boldsymbol{T}_{24 h}$ & $N_{D D}$ \\
\hline Jan & 2080 & 3160 & 3110 & 60 & 2.8 & 496 \\
\hline Feb & 3020 & 4130 & 3610 & 52 & 3.9 & 393 \\
\hline Mar & 4580 & 5470 & 3900 & 39 & 7.4 & 303 \\
\hline Apr & 5460 & 5800 & 3170 & 24 & 12.0 & 138 \\
\hline May & 6730 & 6500 & 2650 & 10 & 17.1 & 24 \\
\hline Jun & 7880 & 7250 & 2320 & 4 & 21.2 & 3 \\
\hline Jul & 8110 & 7650 & 2520 & 8 & 25.2 & 2 \\
\hline Aug & 7410 & 7680 & 3430 & 20 & 24.9 & 6 \\
\hline Sep & 5940 & 7060 & 4500 & 36 & 21.0 & 41 \\
\hline Oct & 4070 & 5520 & 4590 & 50 & 13.9 & 195 \\
\hline Nov & 2760 & 4300 & 4240 & 60 & 8.3 & 352 \\
\hline Dec & 1910 & 2990 & 3060 & 62 & 3.6 & 447 \\
\hline Year & 5010 & 5630 & 3420 & 31 & 13.4 & 2400 \\
\hline \multicolumn{3}{|c|}{$H_{h}:$ Irradiation on horizontal plane $(\mathrm{Wh} / \mathrm{m} 2 /$ day $)$} & \multicolumn{4}{|c|}{ H(90): Irradiation on plane at angle: $90 \mathrm{deg} .\left(\mathrm{Wh} / \mathrm{m}^{2} /\right.$ day } \\
\hline \multicolumn{7}{|c|}{$H_{\text {opt }}$ : Irradiation on optimally inclined plane $\left(\mathrm{Wh} / \mathrm{m}^{2} /\right.$ day $)$} \\
\hline \multicolumn{3}{|c|}{$T_{24 h}: 24$ hour average of temperature $\left({ }^{\circ} \mathrm{C}\right)$} & \multicolumn{4}{|c|}{$N_{D D}:$ Number of heating degree-days (-) } \\
\hline
\end{tabular}

\subsection{PV Power plant}

Some incentives are regulated to increase the RESs capacity in Turkey. KRMN-SNAPS 1.6 MW project aims to generate energy in the facility located within the boundaries of Çumra. The project was established on approximately $21924 \mathrm{~m}^{2}$. This project has a total power of $1791.04 \mathrm{kWp} / 1600 \mathrm{~kW}$. Since solar panels with mono crystal technology are more suitable for the location, a total number of 6180, Solar-world brand 290W mono crystal solar panels, were used. 


\subsection{Utility grid}

PV arrays are connected directly to the utility grid via special equipment to modulate the output of the inverter to be similar to the grid parameters. The power produced from these systems is effectively utilized, as there are no costs due to no energy storage system included. In this way, Energy is directly supplied to feed the electrical network via PV power plants. However, in standalone systems, energy must be instantly consumed through connecting electrical loads or has to be stored in batteries.

\subsection{The Characteristic of PV module}

Experimentally, the PV module is the most important component of the system for its long service life and reliability. Most of the manufacturers give a twenty to twenty-five years guarantee for each modules [19]. The PV modules used in KRMN-SNAPS 1.6 MW PV power plant are of 290Wp rating, made up of monocrystalline. They have an efficiency of $17.03 \%$ under STC and fixed characteristic. It is produced with its linear performance warranty covering a period of 25 years. The values of Voc and Isc are $39.9 \mathrm{~V}$ and 9.97A under STC, respectively. Voltage and current values at maximum power point are $31.4 \mathrm{~V}$ and $9.33 \mathrm{~A}$, respectively. In addition, maximum system voltage and reverse current are $1000 \mathrm{~V}$ and $25 \mathrm{~A}$, respectively, while operating range of $\mathrm{PV}$ module is from $-40^{\circ} \mathrm{C}$ to $85^{\circ} \mathrm{C}$. The solar panels installed in such a way are structure to structure and leg centre-to-centre distance is at $4 \mathrm{~m}$. The distance between modules (Panel to panel) and grounds to lower edge of the module are $25 \mathrm{~mm}$ and $400 \mathrm{~mm}$, respectively. To have a better yield, the modules are cleaned twice in a month.

\subsection{Power conditioning unit/grid tie inverter}

Inverters convert the electricity produced in solar panels from DC to AC used by network. In the KRMN-SNAPS 1.6MW GES project, $72 \mathrm{ABB}$ brand inverters were used. The values of rated DC input power and rated DC input voltage are $28600 \mathrm{~W}$ and $750 \mathrm{~V}$, respectively. The output of the inverter is synchronized automatically with same voltage and frequency as that of grid.

\subsection{Power Evacuation}

The transformer used to transfer the generated energy to the grid has a rated power of 1600kVA. The voltage equals to $380 \mathrm{~V}$ at primary side of the transformer and $33 \mathrm{kV}$ at secondary side that directly connected to grid. The transformer has an efficiency of about $98,83 \%$.

\subsection{The layout of the solar power plant}

KRMN-SNAPS 1.6 MW PV power plant project aims to generate energy in the facility located within the boundaries of Okçu neighbourhood. The entire capacity of the plant is $1.6 \mathrm{MW}$ that built over approximately 21924 square meters of land. The area of this project contained of two block. Each one block is producing a maximum power of about $800 \mathrm{~kW}$, so a summation of 72 circuits are needed to generate a peak of 1.6 MW power. The total number of PV modules is 6180 . A total number of $20 \mathrm{PV}$ modules are connected in series to form one string and a total 72 strings combined to one inverter, 51 of which consist of 4 parallel panels and 21 of which 5 parallel panels. Converted AC power feeds the $380 \mathrm{~V} / 33 \mathrm{kV}$ transformer. The secondary side of the transformer as it mentioned before is directly plugged to the $33 \mathrm{kV}$ high voltage network. The PV power plant is designed in such a way that it has less cost, high reliability, and generating as much energy as possible. During nights, when the solar 
irradiance needed to generate energy is not available, the energy required for operating internal equipment of the solar plant such as lighting, initial starting of the batteries and control room appliances can be supplied from the power of grid.

\subsection{Tilt angle}

The maximum solar irradiance facing on PV array can be obtained by adjusting a suitable slope that is related to the latitude of its location and it known as the tilt angle [26]. The PV power plant implements latest technology for tracking the appropriate angle of solar modules. In addition, a technology that can be controlled manually to adjust the seasonal tilt of PV array is used to absorbe as much irradiance as possible and generating maximum power. In order to obtain more power output by absorbing more solar radiation, the tilt angle of the PV array should be adjusted manually regarding to the different seasons of the year. In order to produce the highest energy depending on the season, the tilt angle can be set to $47.82^{\circ}$ in winter and $17.82^{\circ}$ in summer [29]. However, due to the high labour cost, the tilt angle is set to $25^{\circ}$, which is the optimum value for all the year.

\subsection{Simulation using PVSYST}

The selection of location and system equipment and the modeling of the optional system is very important for the on-grid or off-grid PV power plant to be installed. The PVSYST package program is used for this purpose. 3D simulation of the planned PV power plant can be performed, the performance of the system is obtained, and the shadows falling on the PV modules in the sunrise and sunset can be analysed in real time.

Thus, the performance of the power plant can be evaluated before installation. In this context, the PVSYST analysis was performed for the installed PV system, and the project was conducted jointly for two projects with an analysis power of $800 \mathrm{kWe}$. Analysis revealed that the total annual power generation is $3027 \mathrm{MWh}$. This value is the total electricity production value of the two projects. One of the program outcomes of the simulation results is Fig. 6. 


\begin{tabular}{|c|c|c|c|c|c|}
\hline PVSYST V6.61 & & & & $27 / 04 / 17$ & Page $3 / 3$ \\
\hline \multicolumn{5}{|c|}{ Grid-Connected System: Loss diagram } & \\
\hline $\begin{array}{l}\text { Main system parameters } \\
\text { PV Field Orientation } \\
\text { PV modules } \\
\text { PV Array } \\
\text { Inverter } \\
\text { Inverter pack } \\
\text { User's needs }\end{array}$ & $\begin{array}{r}\text { System type } \\
\text { tilt } \\
\text { Model } \\
\mathrm{Nb} \text {. of modules } \\
\text { Model } \\
\mathrm{Nb} \text {. of units } \\
\text { Unlimited load (grid) }\end{array}$ & $\begin{array}{l}\text { Grid-Co } \\
25^{\circ} \\
\text { Sunmod } \\
6180 \\
\text { TRIO-27 } \\
51.5\end{array}$ & $\begin{array}{l}\text { azimuth } \\
\text { dule SW } 290 \text { mono Pnom } \\
\text { Pnom total } \\
\text { 7_6-TL-OUTD-S1-US } \\
\text { Pnom total }\end{array}$ & $\begin{array}{l}0^{\circ} \\
290 \mathrm{Wp} \\
1792 \mathrm{kWp} \\
27.60 \mathrm{~kW} \text { ac } \\
1421 \mathrm{~kW} \mathrm{ac}\end{array}$ & \\
\hline & $\begin{array}{l}\text { Loss diagram ov } \\
1921 \mathrm{kWh} / \mathrm{m}^{2 *} 10362 \mathrm{~m}^{2} \mathrm{coll} \text {. } \\
\text { efficiency at STC }=17.30 \% \\
3444 \mathrm{MWh} \\
3140 \mathrm{MWh} \\
3027 \mathrm{MWh} \\
3027 \mathrm{MWh}\end{array}$ & $\begin{array}{l}+12.2 \% \\
7.2 .9 \% \\
\\
\\
+0.7 \% \\
-7.9 \% \\
+1.0 \% \\
3.3 \% \\
3 \% \\
0\end{array}$ & $\begin{array}{l}\text { hole year } \\
\text { Horizontal global irradiation } \\
\text { Global incident in coll. plane } \\
\text { IAM factor on global } \\
\text { Effective irradiance on collectors } \\
\text { PV conversion } \\
\text { Array nominal energy (at STC ef } \\
\text { PV loss due to irradiance level } \\
\text { PV loss due to temperature } \\
\text { Module quality loss } \\
\text { Module array mismatch loss } \\
\text { Ohmic wiring loss } \\
\text { Array virtual energy at MPP } \\
\text { Inverter Loss during operation (effi } \\
\text { Inverter Loss over nominal inv. pon } \\
\text { Inverter Loss due to power thresho } \\
\text { Inverter Loss over nominal inv. volt } \\
\text { Inverter Loss due to voltage thresh } \\
\text { Available Energy at Inverter Out, } \\
\text { Energy injected into grid }\end{array}$ & $\begin{array}{l}\text { is } \\
\text { ffic.) } \\
\text { ifiency) } \\
\text { old } \\
\text { itage } \\
\text { hold } \\
\text { tput }\end{array}$ & \\
\hline
\end{tabular}

Figure 6. Grid-connected system: Loss diagram for the KRMN-SNAPS 1.6 MW PV power plant.

\section{Modelling and simulation of the solar power plant}

In the study, a 1600-kW PV array connected to a $33 \mathrm{kV}$ grid via a DC-DC boost converter and a three-phase three-level Voltage Source Converter (VSC) is simulated in MATLAB/Simulink. The screen image of the Matlab/Simulink and schematic diagram for the modeled power plant are given in Fig. 7.

Incremental Conductance and Integral Regulator techniques are implemented in the boost converter as Maximum Power Point Tracking (MPPT) [27]. 5-kHz DC-DC boost converter is used to increase the voltage from PV system output voltage to 750 V DC. The MPPT system automatically varies the duty cycle to generate the optimum voltage and to produce maximum power.

The VSC converts the $750 \mathrm{~V}$ DC link voltage to $380 \mathrm{~V} \mathrm{AC}$ and and maintains unity power factor. A $5 \mathrm{kVAr}$ capacitor bank is used to filter harmonics produced by VSC. $1600-\mathrm{kVA} 380 \mathrm{~V} / 33 \mathrm{kV}$ threephase coupling transformer is utilized for connecting the PV system to the grid. As a utility grid $33 \mathrm{kV}$, $8 \mathrm{~km}$ distribution feeder is used. 


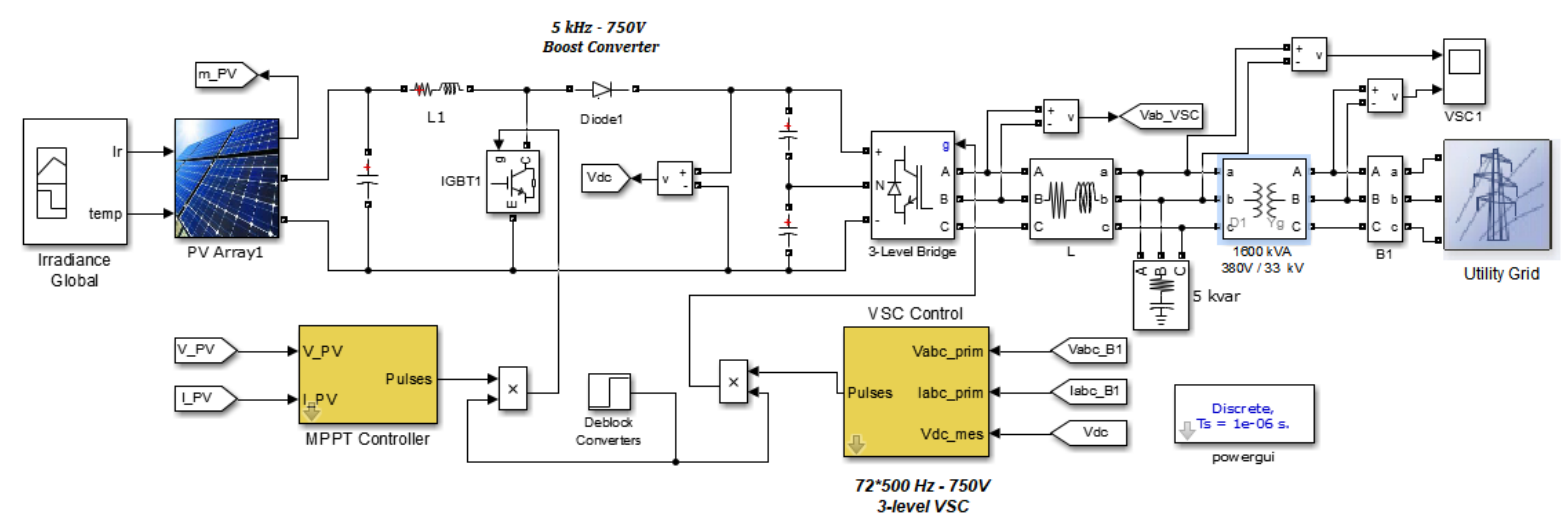

(a)

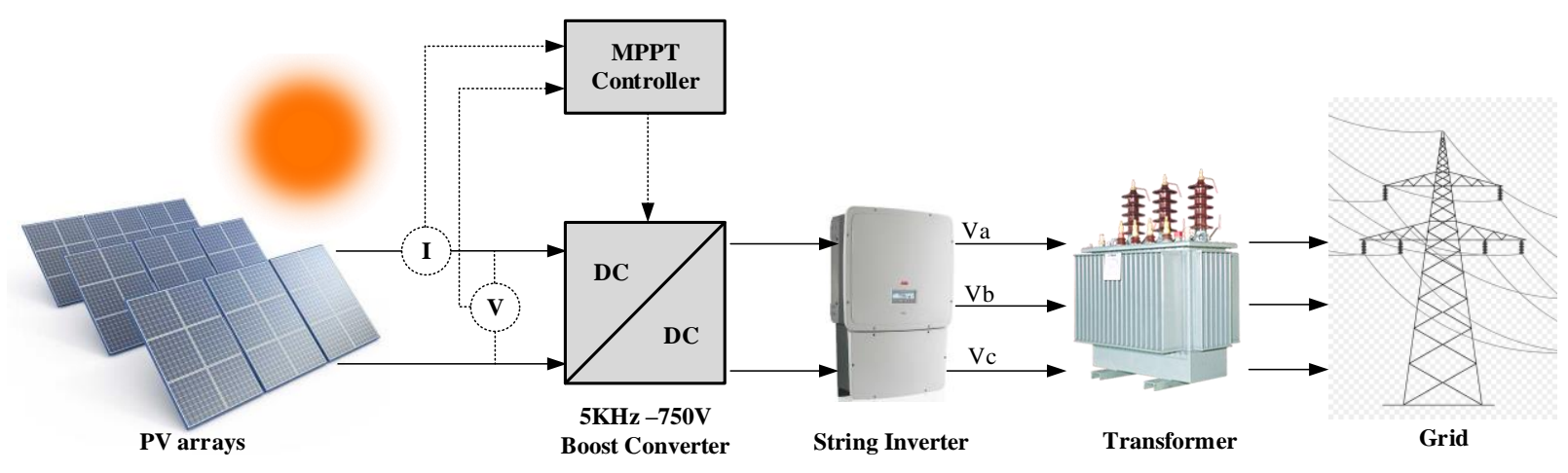

(b)

Figure 7. The modeled power plant: (a) The screen image of the Matlab/Simulink, (b) the schematic diagram.

Located in the sunbelt Turkey, although it differs geographically, it is known that there is no big difference in solar radiation values. In the study, Çumra/Konya region is selected, which is eligible in terms of sunshine duration and solar radiation values. Average daily solar radiation values per month required for analysing the performance of the PV power plant are obtained from PVGIS. One-day global irradiance distribution for one month of each season is shown in Fig. 8 for the sampling of global irradiance $\left(\mathrm{W} / \mathrm{m}^{2}\right.$ per day) data.

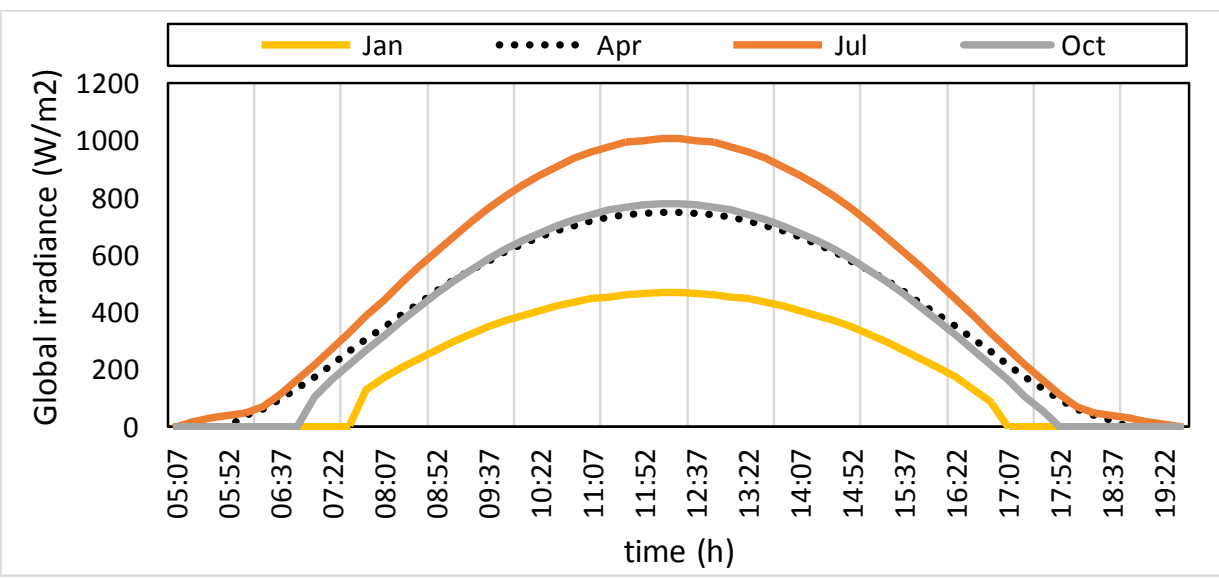

Figure 8. A daily global irradiance $\left(\mathrm{W} / \mathrm{m}^{2}\right.$ per day) distribution of the location of the PV. 
The power produced by the PV power plant is influenced not only by the global irradiance $G_{c e l l}^{e q}$ $\left(\mathrm{W} / \mathrm{m}^{2}\right)$, but by many environmental factors such as the temperature of the PV module $T\left({ }^{\circ} \mathrm{C}\right)$, ambient temperature $T_{a}\left({ }^{\circ} \mathrm{C}\right)$, wind speed $V_{\text {wind }}(\mathrm{m} / \mathrm{s})$ and direction, and relative humidity. Besides, the global irradiance and temperature on individual solar cells are not the same as in the case of partial shading. [28]. A simplified model is used to estimate the temperature of solar cell.

$$
T=0.943 T_{a}+0.028 G_{\text {cell }}^{e q}-1.528 v_{\text {wind }}+4.3 \text {, }
$$

Although this model was originally developed to estimate the temperature of the PV module, it can also be used to estimate cell temperature under partial shading conditions [28]. Environmental factors that directly affect the power produced by the PV module are obtained from Turkish State Meteorological Service and the average daytime temperature of the PV module is calculated for each month. The global irradiance $G_{c e l l}^{e q}\left(W / m^{2}\right)$, ambient temperature $T_{a}\left({ }^{\circ} \mathrm{C}\right)$, wind speed $V_{\text {wind }}(\mathrm{m} / \mathrm{s})$ and the calculated average temperature of the PV module $T\left({ }^{\circ} \mathrm{C}\right)$ are given in Table 2.

Table 2. The calculated average daytime temperature of the PV module on KRMN-SNAPS 1.6MW at a longitude $32.83^{\circ} \mathrm{E}$, a latitude $37.55^{\circ} \mathrm{N}$ and at an altitude of $1012 \mathrm{~m}$.

\begin{tabular}{ccccc}
\hline & $T_{a}$ & $G_{\text {cell }}^{\text {eq }}$ & $v_{\text {wind }}$ & $T$ \\
\hline Jan & 4,9 & 326,1 & 3,4 & 12,8 \\
Feb & 6,8 & 385,6 & 3,1 & 16,9 \\
Mar & 10,8 & 438,4 & 3,5 & 21,4 \\
Apr & 16,0 & 436,9 & 3,8 & 25,9 \\
May & 21,4 & 443,4 & 3,2 & 32,0 \\
Jun & 25,6 & 481,5 & 3,5 & 36,6 \\
Jul & 30,0 & 518,4 & 4,7 & 39,9 \\
Aug & 29,5 & 566,3 & 4,5 & 41,1 \\
Sep & 25,3 & 565,4 & 3,9 & 37,9 \\
Oct & 17,2 & 497,9 & 2,9 & 30,1 \\
Nov & 11,2 & 430,3 & 2,8 & 22,5 \\
Dec & 5,9 & 310,2 & 3,2 & 13,7 \\
\hline
\end{tabular}

The grid power and the grid current curves obtained from the simulation for a day of July are shown in Fig. 9. In the simulation, a one second scale was used instead of an hour as the time axis. These simulations were repeated for hourly global irradiance values shown for four months in Fig. 9 for all months of the year.
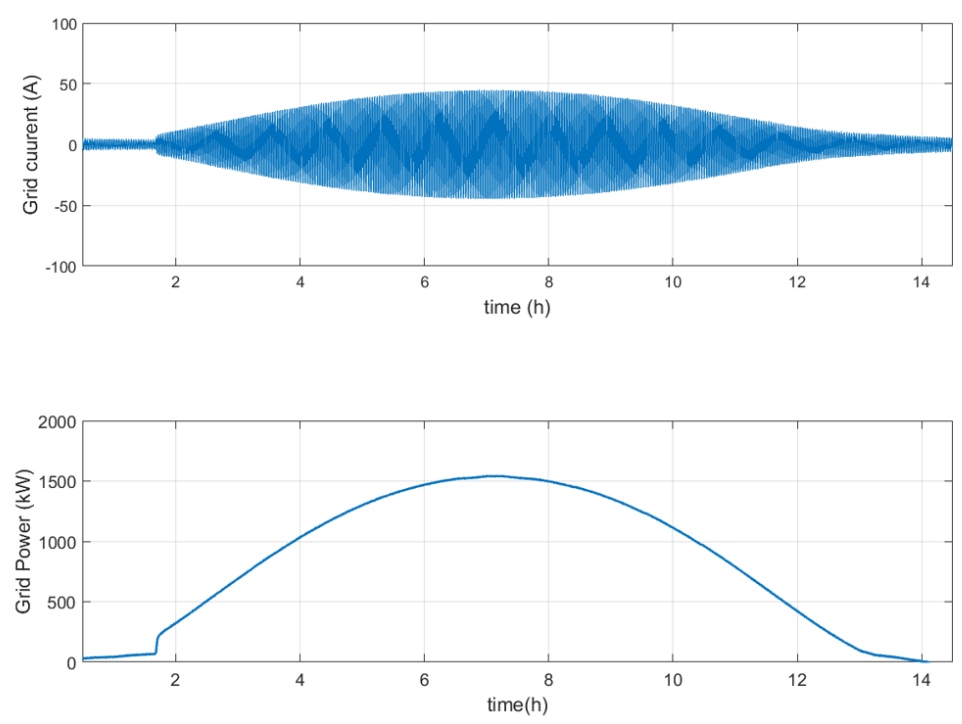

Figure 9. The grid power and grid current curves of the PV power plant obtained from model. 
The power generation values of the power plant were obtained using monthly total global irradiance data obtained from the power curves. Monthly energy generation data obtained from the simulation and monthly generation data of the power plant in 2018 are given in Table 3 . While the actual total energy production of the power plant was $3,122,015.50 \mathrm{KWh}$, it was obtained from the PVYST and our simulation as 3,027,000.00 KWh and 3,008,281.40 KWh, respectively. The same production data are also shown in Fig. 10.

Table 3. The actual and estimated monthly energy generation.

\begin{tabular}{lccc}
\hline Month & $\begin{array}{c}\text { Actual } \\
(\boldsymbol{K W h})\end{array}$ & $\begin{array}{c}\text { Estimated } \\
(\boldsymbol{K W h})\end{array}$ & $\begin{array}{c}\text { Error } \\
(\boldsymbol{K W h})\end{array}$ \\
\hline Jan & $133,864.6$ & $143,451.6$ & -9587.0 \\
Feb & $202,639.2$ & $179,107.5$ & 23531.7 \\
Mar & $256,521.3$ & $233,724.8$ & 22796.5 \\
Apr & $314,250.0$ & $280,145.8$ & 34104.2 \\
May & $303,687.5$ & $289,438.9$ & 14248.6 \\
Jun & $327,629.9$ & $327,663.0$ & -33.1 \\
Jul & $345,619.6$ & $332,743.2$ & 12876.4 \\
Aug & $350,145.1$ & $355,974.6$ & -5829.5 \\
Sep & $293,946.2$ & $282,858.7$ & 11087.5 \\
Oct & $255,618.1$ & $267,434.4$ & -11816.3 \\
Nov & $178,000.0$ & $181,756.0$ & -3756.0 \\
Dec & $160,094.0$ & $133,982.9$ & 26111.1 \\
Total & $\mathbf{3 , 1 2 2 , 0 1 5 . 5 0}$ & $\mathbf{3 , 0 0 8 , 2 8 1 . 4 0}$ & $113.734,10$ \\
\hline
\end{tabular}
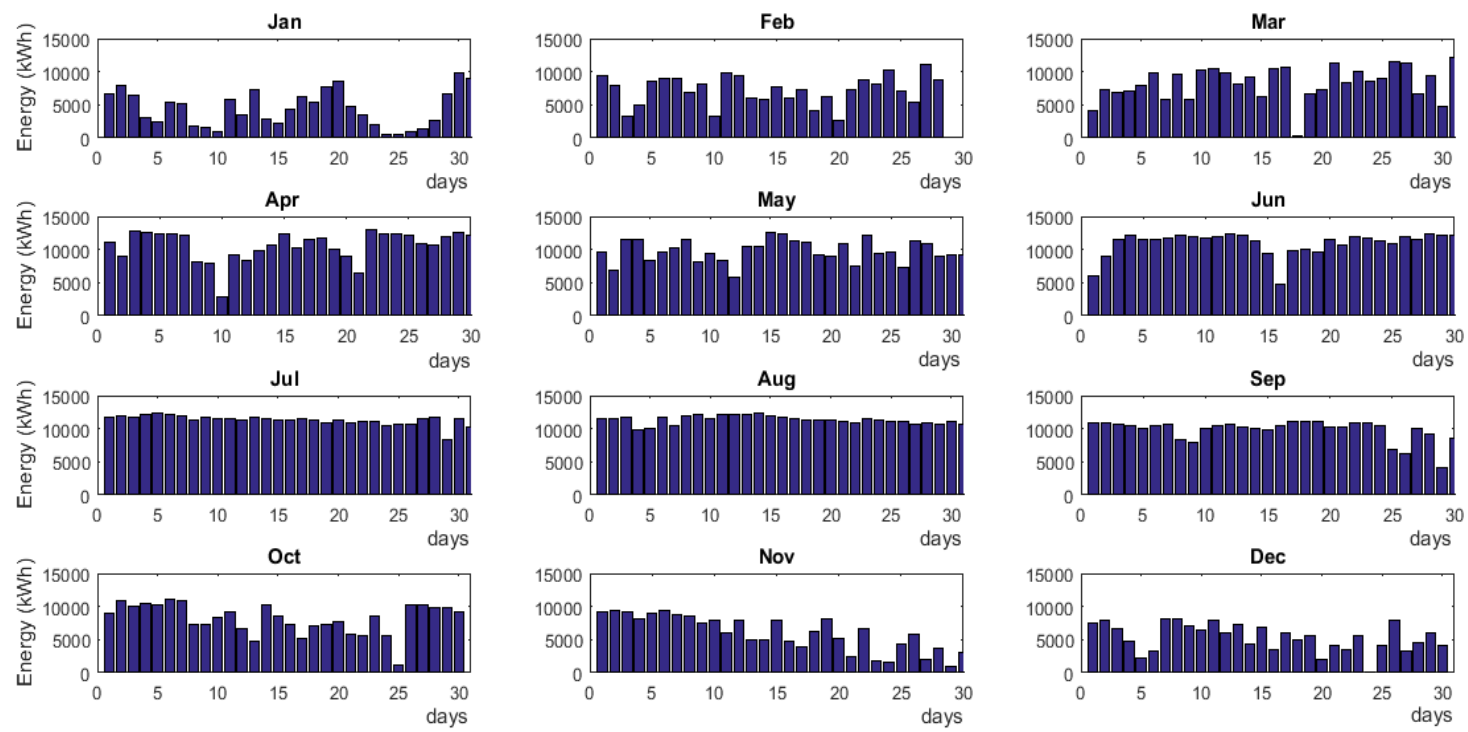

Figure 10. Actual daily energy production of the power plant by months in 2018.

As can be seen, there is no big difference between actual values and simulation values. The energy production of a PV power plant varies depending on many meteorological factors except irradiance. These factors are not the same for all the years. Fig. 10 shows the actual variation in the daily energy production of the power plant by months. There are no major changes in the continental climate in the summer months. However, in the spring, the autumn and especially the winter months, there may be changes in the climate for the different years. Besides, as can be seen in Fig. 11a, in the months of summer, the estimation values were closer to the actual values, but in the months of the other seasons, the error was greater. Considering the meteorological differences that may occur over the years, it is thought that the power plant average production value of many years will overlap with the estimation values. 


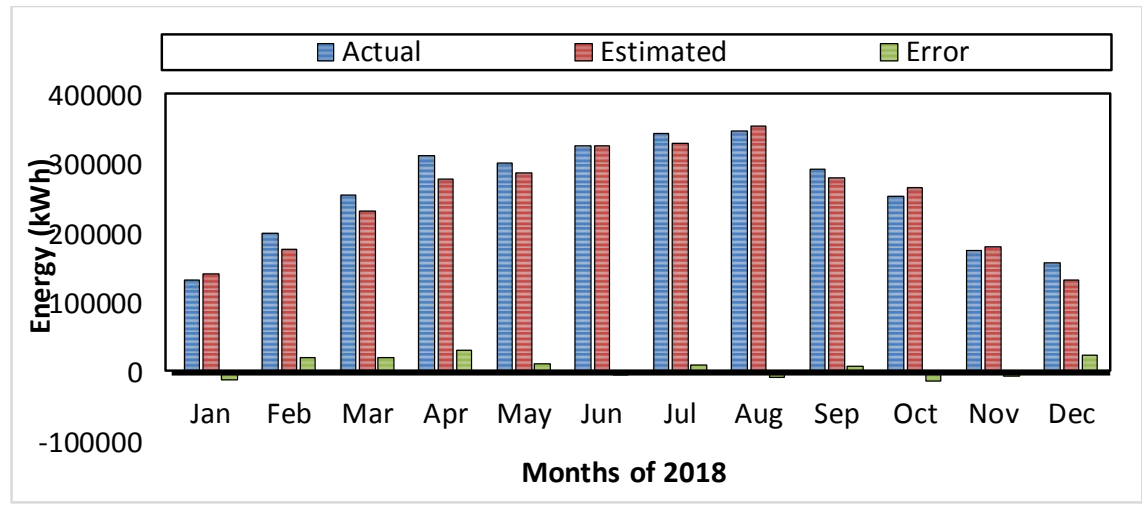

(a)

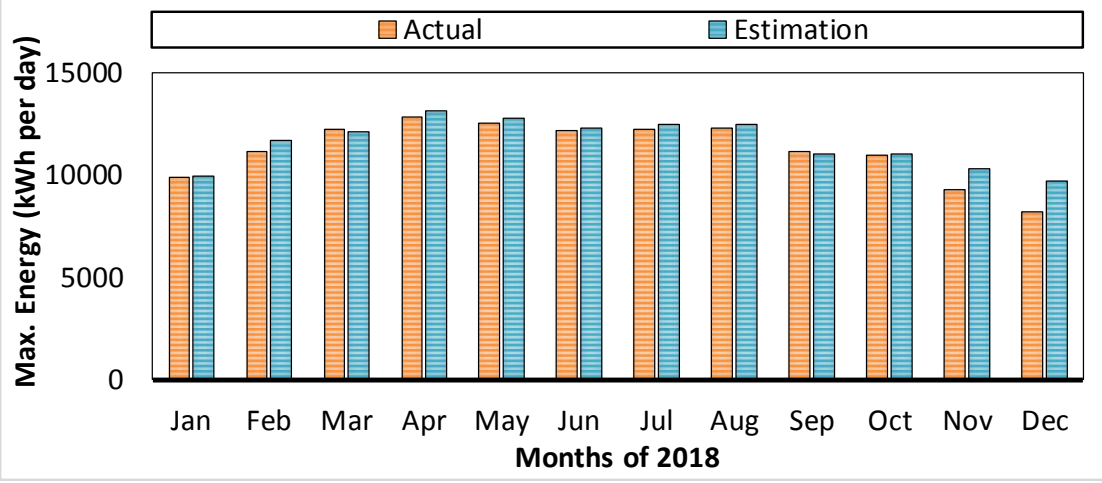

(b)

Figure 11. The actual and estimation energy production values of the PV power plant according to months.

The power plant's daily production data for 2018 are available. In the simulation, daily production estimates for each month were also obtained by using the values of global clear-sky irradiance on a fixed plane, $G_{c}\left(\mathrm{~W} / \mathrm{m}^{2}\right)$. These values are compared with the maximum energy produced by the power plant for each month per day. The actual and estimated values of these data are given in the Fig. 11b. Since the values predicted by the simulation represent the maximum energy that can be generated, the estimation values in all months were higher than the actual values. However, in the warmer months when the meteorological changes were less in years, the values were closer to each other.

\section{Conclusion}

The performance of a PV power plant primarily depends on weather conditions. However, when the long-term data are used, actual production performance of the power plant over the years can be achieved. In the study, 1.6 MW PV power plant installed in Konya Province in the Central Anatolia region of Turkey was evaluated through production performance. The PV power plant is modelled on the bases of parameters that significantly affect performance, such as temperature, radiation, wind, and sunshine duration. The monthly energy production data of the power plant were compared with the actual values. While the actual total energy production of the power plant in 2018 was 3,122,015.50 $\mathrm{KWh}$, it was obtained from the PVYST and the resulted simulation as 3,027,000.00 KWh and $3,008,281.40 \mathrm{KWh}$, respectively. Compared to monthly values, it is observed that especially in the warmest months when climatic changes are low, the estimation values overlap with actual values. The maximum energy that the power plant can produce in a day for each month were also estimated by using clear sky radiation values. The performance and production values of the power plant can be estimated over the years by modelling the PV power plant. 


\section{Acknowledge}

The authors would like to thank KRMN-SNAPS Solar Energy Company for its supports and contributions during this study.

\section{References}

[1] Erdal, G., Erdal H. and Esengün K. (2008). The causality between energy consumption and economic growth in Turkey. Energy Policy, 36(10), 3838-3842.

[2] Neetu and Surender (2017). A Review Paper on Residential Grid Connected Solar Photovoltaic System Using Matlab Simulink. International Journal of Advance Research, Ideas and Innovations in Technology, 3(5), 92-96.

[3] Koç, E., Şenel, M.C. (2013). Dünyada ve Türkiye'de Enerji Durumu -The State of Energy in World and Turkey - General Evaluation. Mühendis ve Makina, 54(639), 32-44.

[4] Ministry of Energy and Natural Resources (MENR) (2017). Electricity generation-distribution statistics according to types of energy resources, Republic of Turkey: Prime Ministry, Ankara, 2017.

[5] Marchal, V., Dellink, van Vuuren, D., Clapp, C., Château, J., Lanzi, E., Magné, B. van Jasper, V. OECD ENVIRONMENTAL OUTLOOK TO 2050, OECD, 2011.

[6] IEA, $\mathrm{CO}_{2}$ Emissions from Fuel Combustion, IEA, 2017, INTERNATIONAL ENERGY AGENCY, 2017. Available: https://www.iea.org/publications/freepublications/publication/ $\mathrm{CO}_{2}$-emissionsfrom-fuel-combustion----2017-edition---overview.html. [Accessed 241 2017].

[7] Nguyen K.Q. (2007). Alternatives to grid extension for rural electrification: Decentralized renewable energy technologies in Vietnam. Energy Policy, 35(4), 2579-2589.

[8] Özçelik, M . (2017). A Micro Hybrid Wind-Pv Based on Grid Energy System With Enhanced Efficiency. European Journal of Technique (EJT), 7 (2), 109-118.

[9] Kabalci, Y., Kabalci E. (2017). Modeling and analysis of a smart grid monitoring system for renewable energy sources. Solar Energy, 153, 262-275.

[10] Kozlova, M., Collan, M. (2016). Modeling the effects of the new Russian capacity mechanism on renewable energy investments, Energy Policy, 95, 350-360.

[11] Akpinar, E. (2018). Statistical analysis of wind speed distribution based on weibull and rayleigh methods of iskenderun-turkey. European Journal of Technique (EJT), 8 (1), 17-34.

[12] Oguz, E, Çimen, H, Oğuz, Y . (2017). Simulation and Power Flow Control Using Switching's Method of Isolated Wind-Solar Hybrid Power Generation System with Battery Storage. Balkan Journal of Electrical and Computer Engineering, 5 (2), 40-49.

[13] Rathore, N. Panwar, N. Renewable energy sources for sustainable development. New Delhi: New India Publishing Agency, 2007.

[14] Hosenuzzaman, M., Rahim, N., Selvaraj, J., Hasanuzzaman, M., Malek, A., Nahar, A. (2015). Global prospects, progress, policies, and environmental impact of solar photovoltaic power generation. Renewable and Sustainable Energy Reviews, 41, 284-297. 
[15] Solangi, K., Islam, M., Saidur, R., Rahim, N., Fayaz, H.(2011). A review on global solar energy policy. Ren Sustain Energy Rev, 15(4), 2149-2163.

[16] Ahmed F., Al Amin, A., Hasanuzzaman, M. Saidur, R. (2013). Alternative energy resources in Bangladesh and future prospect. Renew Sustain Energy Rev, 25, 698-707.

[17] Selvara, J. Rahim, N.A. (2009). Multilevel Inverter For Grid-Connected PV System Employing Digital PI Controller. IEEE Transactions On Industrial Electronics, 56(1), 149-158.

[18] Kaya, D. (2006). Renewable energy policies in Turkey. Renewable and Sustainable Energy Reviews, 10, 152-163.

[19] Goetzberger, A. Hoffmann, V. Photovoltaic Solar Energy Generation, Germany: SpringerVerlag Berlin Heidelberg, 2005.

[20] Sudeepika, P., Gayaz Khan, G. (2014). Analysis Of Mathematical Model Of PV Cell Module in Matlab/Simulink Environment. International Journal of Advanced Research in Electrical, Electronics and Instrumentation Engineering, 3(3), 7823-7829.

[21] Luque, A. Hegedus, S. Handbook of Photovoltaic Science and Engineering, England: John Wiley \& Sons Ltd, 2003.

[22] Sonnenenergie D. G. F. Planning and Installing Photovoltaic Systems: A guide for installers, architects and engineers, Berlin: Earthscan, 2008.

[23] Tsai, H.-L., Tu, C.-S., Su Y.-J. (2008). Development of Generalized Photovoltaic Model Using MATLAB/SIMULINK, in Proceedings of the World Congress on Engineering and Computer Science WCECS, San Francisco, USA.

[24] Villalva, M., Gazoli, J., Filho, E. (2009). Comprehensive approach to modeling and simulation of photovoltaic arrays. IEEE Trans Power Electron, 24, 1198-1208.

[25] Reddy, N.A., Raju, K.D. (2017). Mathematical Modeling of Soft Switched Single Stage Multistring Inverter with Multi-Rated ETT Photovoltaic Modules. Inter. J. Advance Research, Ideas and Inovations in Tech., 3(1), 489-499.

[26] Labed, S., Lorenzo, E. (2004). The impact of solar radiation variability and data discrepancies on the design of PV systems. Renewable Energy, 29(7), 1007-1022.

[27] de Brito, M., Sampaio, L., Jr., L., e Melo, G., Canesin, C. (2011). Comparative Analysis of MPPT Techniques for PV Applications, in IEEE, 2011 International Conference on Clean Electrical Power (ICCEP), Ischia, Italy.

[28] Gao, Y., Dong, J., Isabella, O., Santbergen, R., Tan, H., Zeman, M., Guoqi, Z. (2019). Modeling and analyses of energy performances of photovoltaic greenhouses with sun-tracking functionality, Applied Energy, 233-234, 424-442.

[29] PVGIS. Photovoltaic Geographical Information System - Interactive Maps. European Commission, Joint Research Centre, Institute for Environment and Sustainability Renewable Energies Unit, [Online]. Available: http://re.jrc.ec.europa.eu/pvgis/apps4/pvest.php. [Accessed 12 March 2019]. 